NBER WORKING PAPER SERIES

\title{
UNIONIZATION AND FIRM PERFORMANCE: THE IMPACT \\ ON PROFITS, GROWTH AND PRODUCTIVITY
}

\author{
Kim B. Clark \\ Working Paper No. 990 \\ NATIONAL BUREAU OF ECONOMIC RESEARCH \\ 1050 Massachusetts Avenue \\ Cambridge MA 02138 \\ September 1982
}

This research has been supported by the Division of Research of the Harvard Business School and the Labor Studies program of the National Bureau of Economic Research. The Strategic Planning Institute provided access to the PIMS data and supported the statistical analysis through a computer grant. I am indebted to David Ellwood, Therese Flaherty, Richard Freeman, David Garvin, Lawrence Summers and participants in various NBER seminars for comments and suggestions. Phil Jarimyszin and Lorie Wilson provided excellent research assistance. The research reported here is part of the NBER's research program in Labor Studies. Any opinions expressed are those of the author and not those of the National Bureau of Economic Research.

Working Papers are a series of manuscripts in their draft form. They are not intended for circulation or distribution except as indicated by the author. For that reason Working Papers may not be reproduced or distributed without the written consent of the author. 
Unionization and Firm Performance:

The Impact on Profits, Growth and Productivity

\section{ABSTRACT}

This paper examines the impact of unionization on profitability, growth and productivity using time series data on over 900 product line businesses in the North American manufacturing sector (predominantly U.S.). The first section of the paper develops a simple theoretical framework for studying the effect of the union on firm performance. A key result of this analysis is that information about union wage and productivity effects is not sufficient to permit prediction of the sign (or magnitude) of consequent changes in the rate of return on capital; one must know the parameters of production and demand. Expanding the model to allow for the effects of market structure and alternative bargaining regimes establishes the need to examine several indicators of firm performance in assessing the impact of the union. The empirical analysis reveals sizeable negative union effects on profitability, but growth, productivity and the capital-labor ratio appear to be little affected by unionization in this data. The data are thus consistent with a model of union-firm interaction in which collective bargaining affects the distribution of profits, but leaves real magnitudes unchanged. The evidence suggests, however, that unionization may have longer term implications for efficiency since the impact on profitability appears to fall most heavily on firms with relatively little market power.

Kim B. Clark

Morgan 8 Harvard Business School Boston, MA 02163

(617) 495-6303 
The history of collective bargaining in the US has been marked by dramatic episodes of confrontation which underscore the change unionization brings to the operation of an enterprise. Yet strikes and lockouts are only the most visible of pervasive differences in the employment relationship in organized establishments. It is well known that a wide variety of changes in the employment contract and adjustments in management procedure followed the wave of organizing begun in the $1930 \mathrm{~s} .1$ In spite of the diffusion of many practices associated with collective bargaining (seniority, grievance systems) recent research has revealed the continuing existence of important differences between union and nonunion establishments in policies governing compensation, exit and entry, dispute resolution and internal promotion. ${ }^{2}$ As Freeman has argued, these differences reflect the complexity of the employment relation and the potential for collective action to yield a different set of conditions in the presence of substantial information problems. Yet little is known about the effect of these differences on the profitability of the firm.

The large body of evidence on the union wage effect, for example, is not sufficient to establish a union effect on profits. Other changes in the employment contract may lead to firm or worker adjustments which either reinforce or offset the effect of increased wages on costs. The potential negative effects of work rules and protection of malfeasance are well known, but some recent evidence suggests that unionization may also lead to improvements in operations through reductions in turnover, and changes in management procedures. ${ }^{3}$ These considerations have motivated statistical comparisons of union wage and productivity differentials. Freeman and Medoff have stated the assumptions underlying this approach quite clearly: 
...Unionism may increase productivity in some settings and decrease it in others. If the increase in productivity is greater than the increase in average unit costs due to the union wage effect, then the profit rate will increase; if not, the rate of profit will fall.4

As I show below, this inference is only valid under quite restrictive assumptions. In general, it is not possible to infer changes in the rate of return on capital from information on union wage and productivity effects. The impact of the union on a firm's economic performance depends on the wage setting process, the structure of markets, and the technology of production. Although an analysis of wages and productivity provides useful information about the operation of the firm under collective bargaining, an assessment of the impact of the union on profitability requires a direct examination. Furthermore, evaluating the efficiency consequences of unionization requires analysis of several measures of the firm's economic performance. Unionization works through more than one mediating factor, and the impact of the union on a given measure of firm performance depends on the particular context in which bargaining and production take place. Thus, focus on a single indicator can be misleading.

This paper uses microeconomic data on over 900 product line businesses to gauge the impact of the union on economic performance. In the first part of the paper, relatively simple models of the firm are used to derive a number of hypotheses about the effect of unionization. An important aspect of the analysis is the role of market structure and the institutional context of the wage setting process. A clear implication of the theoretical analysis is the need to examine several indicators of firm behavior in order to draw inferences about the operation and consequences of collective bargaining. Part II presents an empirical analysis of unionization and interfirm differences in the rate of return on capital, 
sales growth, and productivity. Part III provides a brief summary and suggestions for further work.

\section{A Theoretical Framework}

The starting point for the models developed in this section is a single product monopolist with a constant elasticity demand curve and a constant returns production process. Although pure monopolies are rare, analysis of this case is useful because most of the firms to be dealt with in the empirical work face a downward sloping demand curve and enjoy some barriers to entry. Unionization enters the analysis in two ways. I first treat the collective bargaining process as a problem of selecting a point on the firm's labor demand curve. In this context, the firm is assumed to be free to choose the level of employment and to adjust other decision variables in order to maximize profits. The second treatment of unionization allows the two parties to arrive at a wage/ employment combination off the labor demand schedule. In this case, output and input decisions depend on the objectives of the parties and specification of the bargaining process.

The analysis yields results on several measures of firm behavior, but focuses particularly on the rate of return on capital as the basic measure of profitability. While a given firm's objective is to maximize total profits, some way must be found to scale total profits in order to provide a basis for comparison with other (possibly different-sized) enterprises. Because theory suggests that risk-adjusted returns should be equalized across industries and firms, the rate of return on capital has been widely used in empirical work. Other indicators of profitability, including various pricecost margins, have been suggested in the literature and will be examined in turn. 
The Monopoly Case

The firm in this model is a profit maximizing monopolist facing a demand curve with constant elasticity. For simplicity, the technology is specified to be CES with constant returns. ${ }^{5}$ The supply of factors is perfectly elastic. Initially, I assume that the only effect of unionization is an increase in the wage. The firm takes the wage as given and chooses a level of employment consistent with its labor demand schedule. For the moment, let the union markup over the competitive wage be determined outside the model. The wage relationship can be written as:

$$
\mathrm{w}_{\mathrm{u}}=\mathrm{w}_{\mathrm{o}}(1+\mathrm{mU})
$$

where $w_{0}$ is the competitive wage, $m$ is the percentage markup and $U$ is a dummy variable which has the value 1 if the firm is unionized. The effect of unionization on the firm can be developed from the solution of the firm's maximization problem, given by: 6

$$
\max _{K, L} \pi=f(K, L)(1-1 / \eta)_{-w_{0}} L-r_{0} K
$$

The first order conditions can be used to derive expressions for the optimal quantities of capital and labor. These, in turn, can be substituted into the definition of total cost to yield a cost function. Under constant returns (and perfectly elastic factor supplies) this function has the form:

$$
C=A_{o}^{-1} g(w, r) Q
$$

where $g(w, r)$ is marginal cost, and $A_{0}$ is an index of total factor productivity. The optimal level of output is determined by the equality of marginal revenue and marginal cost. With a constant demand elasticity, marginal revenue is simply $\left(1-\frac{1}{\eta}\right) Q$ so that at the optimum (ignoring the 
constant $\left.A_{0}\right):$

$$
Q *=\left[g(w, r) \frac{1}{1-\frac{1}{\eta}}\right]^{-\eta}
$$

Since the elasticity of marginal cost with respect to changes in the wage is simply $\alpha$, labor's share, equation (4), implies that the elasticity of output with respect to wage changes is $-a \eta$.

Using (4) and the definition of profits, total profit can be written as :

$$
\pi=\left(\frac{1}{1-1 / \eta}\right)^{-\eta}\left(\frac{1}{\eta-1}\right)[g(w, r)]^{1-\eta}
$$

Thus, the elasticity of total profits with respect to changes in the wage is:

$$
\eta_{\pi w}=\alpha(1-\eta)
$$

These results provide clear predictions of the effect of unionization on output, the capital-labor ratio and total profits. Assuming $m>0$, unionization leads to a decline in output of anm percent, a decline in total profits of $\alpha(1-\eta) \mathrm{m}$ percent, and a percentage increase in the capital-labor ratio of $\sigma \mathrm{m}$, where $\sigma$ is the elasticity of substitution.

The effect on the rate of return on capital is less clear-cut. Clearly, as long as $\eta>1$, unionization will lower total profits in the absence of offsetting productivity effects. If the stock of capital were unchanged, the rate of return on capital would also decline. But the capital stock will not remain constant. Whether it rises or falls depends on scale and substitution effects. In the case of a CES production function, this elasticity is:

$$
\eta_{\mathrm{kw}}=\alpha(\sigma-\eta)
$$

Note that the scale effect is just the effect on output ( $-\alpha \eta)$ because of the constant returns assumption. 
The net effect of an increase in the wage on the return on capital can be derived by comparing (6) with (7) so that:

$$
\eta_{(\pi / k) w}=\alpha(1-\eta)-\alpha(\sigma-\eta)=\alpha(1-\sigma)
$$

Thus, the rate of return on capital will fall with an increase in the wage if the elasticity of substitution is greater than one. ${ }^{7}$ Otherwise, the return will rise.

How will these results change in the presence of a union productivity effect? Following previous work, the productivity effect can be characterized by a simple change in $A$, the irdex of total factor productivity. Let $A_{0}$ be the index before unionization, and $d$ the union effect on productivity. 8 The index after unionization is then:

$$
A_{u}=A_{0}(1+d U)
$$

One way to illustrate the effects of unionization is to separate the effect of the productivity index from the effects of factor prices. Changes in total factor productivity have a direct effect on costs, while the wage effect depends on labor's share. The optimal level of output with both wage and productivity effects is:

$$
Q^{*}=\left[A(1+d U]^{\eta}\left[g\left(w_{o}(1+m U), r\right) \frac{1}{1-1 / \eta}\right]^{-\eta}\right.
$$

In elasticity terms, the effect of unionization on output is then:

$$
\eta_{\mathrm{qu}}=-\eta(\alpha \mathrm{m}-\mathrm{d})
$$

Thus, if the productivity effect is positive, and equal to $\alpha \mathrm{m}$, there will be no change in output under unionization. A negative productivity effect will simply reinforce the wage effect.

Equation (10) supports a similar conclusion about total profits. But the effect on the return on capital depends on relative changes in the capital stock. Using the notation developed in (10), the effect of unionization on total profits can be written as: 


$$
\eta_{\pi u}=(1-\eta) \quad(\alpha m-d) .
$$

With a CES, constant returns production function, the expression for the effect on capital is:

$$
\eta_{k u}=d(\eta-1)+\alpha m(\sigma-\eta)
$$

Inspection of (12) and (13) reveals that the productivity effect enters symmetrically, and thus has no effect on the rate of profit. Changes in the rate of profit depend on the elasticity of substitution:

$$
\begin{aligned}
\eta_{(\pi / k) u} & =(1-\eta) \quad(\alpha m-d)-[d(\eta-1)+\alpha m(\sigma-\eta)] \\
& =\alpha m[1-\sigma]
\end{aligned}
$$

As before, the rate of profit will rise or fall depending on $\sigma_{>}^{<} 1$. In this context, it is not possible to infer changes in the rate of profits from information on wage and productivity effects unless $\sigma$ is known. Wage and productivity comparisons do yield clear inferences about total profits, output and the capital-labor ratio.

Alternative Bargaining Models

The above analysis assumes that the wage-employment bargain lies on the firm's labor demand schedule. This assumption has significant analytical power, since it allows one to treat the problem of unionization using the theory of derived demand. However, two related aspects of the approach suggest the need for further analysis. First, a variety of bargaining issues associated with work rules, the introduction of technology and compensation seem to involve wage/employment combinations off the firm's labor demand schedule. ${ }^{9}$ Second, in a bargaining context, points on the labor demand schedule are unlikely to be Pareto efficient. Unless the union has a fixed coefficient objective function, the contract curve will be off the demand curve. Since either the firm or the union could be made better off without reducing the 
welfare of the other party, it seems reasonable to expect that attempts would be made to move toward a more efficient bargain. 10

Any attempt to achieve a bargain off the demand curve greatly complicates attempts to gauge the union's impact on firm performance. It is necessary not only to specify the technology and demand parameters, but the objective of the union and the specific bargaining process, including some statement of relative power must also be brought into play. A definitive treatment of those issues will not be attempted here. The more modest purpose of this section is to illustrate the implications of alternative bargaining setups using a relatively simple bargaining model.

For our purposes, the complexity of the union-management bargaining process can be simplified to the problem of choosing a point on a contract curve defined by the objective functions of the two parties. The assumption that the agreement lies on the contract curve implies that bargaining extends beyond wage rates to include, perhaps implicitly, the level of employment, and other aspects of production. ${ }^{11}$ A variety of instruments are available that effectively constrain production adjustments by the firm without involving an explicit agreement on the number of workers, or the total hours of work. Work rules and provisions covering new technology, can be interpreted as measures to achieve a bargain off the demand curve. Moreover, various compensations rules (royalty payments, profit sharing, equipment differentials) can have similar effects. ${ }^{12}$

Although in practice, the outcome of bargaining where such provisions play a role will depend on the character and distribution of information, I will abstract from such difficulties here. I assume that sufficient information is available to allow the firm and the union to reach the contract curve. 
As in the previous section, the analysis concerns a single product monopoly operating under conditions of constant returns. The objective of the firm remains the maximization of profits. The union's objective is to maximize the difference between the wage bill and the opportunity cost of employment in the firm. ${ }^{13}$ This can be written as $\mathrm{H}=\left(\mathrm{w}-\mathrm{w}_{0}\right) \mathrm{L}$, where $\mathrm{w}_{0}$ is the wage in the absence of unionization, $w$ is the realized wage and $L$ is labor input. The maximization problem confronting the firm and the union can be treated as a two-step process. In the first step, the joint interest or surplus of the two parties is defined and maximized by adjusting those variable which do not vary along the contract curve. The division of the surplus is determined in the second step through some process which reconciles competing claims.

Given the objectives specified above, the maximization problem can be written as:

$$
\max _{K, L} S=P Q-w L-r K+\left(w-w_{0}\right) L
$$

or

$$
\max _{K, L} S=P Q-w_{0} L-r K
$$

The addition of the two objectives results in a maximand which is identical to the firm's objective in the nonunion setting. Under the bargaining regime, the firm makes production decisions as though it faced the nonunion wage. Thus, the stock of capital and the level of employment (and thus output and price) are unchanged after unionization. Only the wage varies along the contract curve. Given product demand and the opportunity cost of labor, the interests of the two parties are maximized at the point of maximum monopoly profits. The division of the surplus depends 
on the form of the objective functions, the distribution of power and the particular decision rules which are assumed to apply. Although the total surplus is unchanged after unionization, workers share in profits, and thus reduce returns to the firm. With capital unchanged, the bargaining model unambiguously predicts a decline in the rate of return on capital.

The presence of union productivity effects in the bargaining context may lead to paradoxical results. A positive union effect, for example, results in an increase in output and total profits (before divisions with the union). Since the firm makes input and output decisions as though it faced nonunion wage rates, the union productivity effect has the same impact as would neutral technological change in the nonunion setting. The firm behaves as though marginal costs had declined and increases output (and lowers prices). Since the elasticity of demand exceeds one, the stock of capital and labor input are increased in proportion. ${ }^{14}$ If the productivity effect is large enough, it may increase total profits sufficiently to leave the firm's profits unchanged after division with the union. Even in this case, however, the rate of return on capital will fall, since the stock of capital will have increased.

\section{The Implications of Market Structure}

The analysis thus far has been limited to the monopoly case. Differences in product markets are likely to influence the impact of the union in two ways. For any given wage or productivity effect, the response of the firm to unionization may depend on the nature of competition it faces. Furthermore, the size of the wage and productivity effects themselves may depend on the structure of markets. This is particularly evident in the bargaining model, where relative power influences the division of total profits. The 
introduction of market structure considerations requires a richer theoretical framework than the monopoly model provides. Note that the effect of the union on profitability in that model does not depend on the elasticity of demand. Thus, little can be learned about market structure and the impact of the union on profits in the single firm framework where competition is defined solely in terms of the shape of a constant elasticity demand curve. The development of a full-scale model of competition in oligopolies is beyond the scope of this paper. It is possible, however, to suggest a number of important relationships between firm performance and unionization in different market settings using a fairly simple theoretical framework.

In the model developed here, the firm undergoing unionization (firm 1) produces a differentiated product, and has several competitors. Demands are assumed to be interdependent. In order to simplify the notation, it will be useful to group the firm's competitors into a composite, representative firm, firm 2. Technology is assumed to be constant returns, and may differ in the two firms. The reaction of firm 1 to unionization will depend on the degree of product differentiation and the output and pricing rules which govern competition. A convenient assumption is that the firms reach equilibrium by maximizing joint profits. This framework ignores interesting complications (e.g., unions and rivalrous behavior) but is sufficiently rich to illustrate the basic issues.

Expressed in inverse form, firm l's demand curve is:

$$
P_{1}=f\left(q_{1}, q_{2}\right)
$$

with the partial derivatives of (17) assumed to be negative. Firm l's profits can be written as:

$$
\pi_{1}=q_{1}\left[f\left(q_{1}, q_{2}\right)-a_{1}\right]
$$


where $a_{1}$ is marginal cost, and $q_{1}, q_{2}$, are equilibrium values. With only a wage effect, unionization raises $a_{1}$ and the effect on $\pi$ is given by: 15

$$
\frac{\partial \pi_{1}}{\partial a_{1}}=\frac{\partial q_{1}}{\partial a_{1}}\left[f\left(q_{1}, q_{2}\right)-a_{1}\right]+q_{1}\left[f_{1} \frac{\partial q_{1}}{\partial a_{1}}+f_{2} \frac{\partial q_{2}}{\partial a_{1}}-1\right] \text { (19) }
$$

The first term in (19) is the output effect, while the second term captures changes in the price-cost margin. It is the latter which is of central importance in determining the effect of unionization on the return on capital in different competitive situations. The effect of a wage increase on firm I's capital stock will depend on the output effect and the elasticity of substitution. Since output affects profits and capital symmetrically under constant returns, output effects will cancel out. Changes in the return on capital will depend only on changes in the price-cost margin and the extent of substitution in production. However, variation in union impact with variations in market structure will depend solely on changes in the pricecost margin, since there is no reason to expect $\sigma$ to vary with the structure of the product market.

As specified in (19) the change in the price of firm l's product is the sum of two effects: a movement along its demand curve, and the reaction of competitors which causes a shift in demand. Whether the price-cost margin rises or falls in response to changes in costs is indeterminate. However, if the own elasticity of demand is roughly constant, then $\mathrm{f}_{1} \frac{\partial \mathrm{q}_{1}}{\partial \mathrm{a}_{1}} \cong 1$, and, movement along the firm's demand curve will leave the price-cost margin unchanged. Since $f_{2}<0$, and since competitors will react to a rise in $a_{1}$ by increasing $q_{2}$, firm l's price-cost margin will fall. The implication is that an increase in costs in a competitive environment (i.e., high values of $\mathrm{f}_{2} \frac{\partial \mathrm{q}_{2}}{\partial \mathrm{a}_{1}}$ ) will put a squeeze on margins, more so than if the firm had substantial market power. 
A further example suggests the plausibility of this result. Consider the case in which the newly unionized firm 1 is one of many small firms in an industry with a dominant firm. Suppose further that the small firms largely accept the dominant firm's price (products are only moderately differentiated) which is set in the usual way on the basis of a net demand function. A rise in $a_{1}$ in this setting (with the costs of other firms constant) is likely to lead to a declining price-cost margin for firm 1 since a relatively small firm will be unable to recoup cost increases by raising prices. In contrast, if firm 1 were the dominant firm, the price-cost margin would be likely to change very little. ${ }^{16}$ As long as an identical union wage differential was imposed in the two settings, and as long as $\sigma$ was identical, the effect on the return on capital would be more negative where firm 1 had less power. ${ }^{17}$ While intuitively reasonable, the notion that unionization has a stronger impact on less powerful firms is only one among several theoretically possible outcomes. ${ }^{18}$ Strong conclusions must await empirical evidence.

The effect of market structure on the union's impact is likely to be unaffected by productivity effects. As long as the union effect on productivity does not vary with market structure, and unless unionization leaves costs unchanged, qualitative conclusions about the effect of differences in competitive environments will be unchanged from the wage only 'case. With unchanged costs, however, the profit effect depends only on the elasticity of substitution and is thus independent of market structure.

Conclusions about the effects of market structure are somewhat stronger if a bargaining model of wage determination is introduced. The analysis is simplified because a negotiated wage change in the 
bargaining model leads to no changes in output or prices in the unionized firm. While the profits of firm 1 are reduced, competitors are unaffected. From the competitors' standpoint, unionization of firm 1 only affects how the total profits of firm 1 (which are unchanged) are allocated. In this context the effect of different competitive environments is straightforward. Since unionization does not affect real variables, the issue is how post-union returns to the firm compare to the pre-union level of profitability. As long as the wage differential is the same in different competitive environments, the union effect on profits will depend on how pre-union profits per unit of labor vary with the competitive environment. Under the usual assumptions about firm behavior, this ratio will be higher and, consequently, the firm's share of total profits will be higher, the greater the market power of the firm. In effect, the more competitive firms must give up a larger fraction of lower total profits if the condition of constant wage differential is to be satisfied. 19 A union productivity effect does not change the conclusion. If unionization affects productivity, the level and price of firm l's output will change, and adjustments will be made among competitors in order to maximize joint profits. Consider the case of a positive union effect, accompanied by a wage increase, both of which are independent of market structure. Consistent with the two-stage bargaining procedure developed above, the firm is assumed to incorporate the productivity effect into its calculation of total profits, before the surplus is divided. Thus, the productivity change affects the calculus of joint profit maximization in a manner exactly analogous to equation (19). As before, assessment of the difference in union impact in different 
competitive settings depends on changes in the price-cost margin. Let the relationship between total profits before and after the productivity effect be given by $\pi_{1}^{*}=\left(1+\delta_{1}\right) \pi_{1}^{0}$, where $\delta_{1}$ captures the cross-price effects of competitors (the own price effect is assumed to just offset the cost change) which will be positive. The firm's share of total post-union profits is $\pi_{1} / \pi_{1}^{*}=\theta_{1}$, and the union effect on profits is given by $\pi_{1} / \pi_{1}^{0}=\theta_{1}\left(1+\delta_{1}\right)$. (Similar expressions can be written for the firm in the less competitive setting - firm 2.) As in the wage effect only case, the constant wage differential implies that $\left(\left(1-\theta_{1}\right) \pi_{1}^{*}\right) / L_{1}=\left(\left(1-\theta_{2}\right) \pi_{2}^{*}\right) / L_{2}$. Substituting for $\pi_{1}^{*}$, and recalling that $\pi_{1}^{*} / L_{1}<\pi_{2}^{*} / L_{2}$, the equality of wages implies that $\theta_{1}\left(1+\delta_{1}\right)<$ $\theta_{2}\left(1+\delta_{2}\right)$. Thus, the union has a smaller impact in the less competitive envi ronment. 20

Market Structure and Wage/Productivity Effects

The simple model of oligopoly developed above suggests that competition increases the response of firm performance to unionization. This result rests heavily on the assumption that wage and productivity effects are independent of market structure. Yet it has long been argued that wage determination is affected by structural conditions in the product market. ${ }^{21}$ Moreover, the nature of competition is 1ikely to affect both the opportunity and the incentive for the firm to improve productivity after unionization. In both cases, however, the direction of the effect is ambiguous. Although definitive predictions cannot be derived, theoretical considerations together with existing empirical evidence can be used to provide insight into likely directions of influence. 
In the case of compensation two conflicting effects govern the relationship between market structure and the union wage effect. Firms with substantial market power tend to earn above-average returns, which become the target of union negotiations. From the union's perspective high profits increase the firm's ability to pay and constitute a legitimate ground for high wage demands. Furthermore, if returns substantially exceed the opportunity cost of capital, a high wage level need have little effect on the firm's long-term survival. In contrast, unionization of a firm operating in a highly price-competitive market may lead to very low long-term wage gains. Either the union will recognize the need to moderate demands, or the firm will not survive. Thus the only competitive firms observed are those with wages close to nonunion levels.

The foregoing argument ignores the role of relative power in wage determination. While it is true that in the extreme case of perfect competition the scope for wage gains is constrained, within the set of firms exercising some market power, the union wage differential may be affected by the relative power of the employer. Because of its ability to weather a strike, a firm with few competitors and substantial financial resources may be less willing to make concessions than a firm with less market power. Thus, unionization of a firm with high market share may not lead to a larger differential over nonunion wages. This is particularly true if the high market share firm has already foregone some profits by paying relatively high wages. The desire to increase an applicant queue, to avoid community censure or unionization have been suggested in the literature as explanations of a positive correlation between market share or concentration and the level of wages. In such a setting, the added impact of unionization may be small. 22 
Existing empirical evidence on the relationship between market structure and the union wage differential in U.S. manufacturing suggests that the constraint of competition and the power of the firm tend to be offsetting. Work by Weiss, and Freeman and Medoff suggests no statistically significant relationship between concentration and the union wage effect. 23 While the direction of the effect is generally negative (i.e., the differential is smaller in concentrated industries) large standard errors preclude strong inferences. The implication is that the wage effect is unlikely to offset, and may reinforce the tendency for the union impact on profits to be more negative as the number of competitors increases and as market share declines.

Whether this result continues to hold in the face of productivity effects, however, is unclear. If positive union productivity effects are larger and/or more likely in more competitive settings, the union impact on profitability (and output) could be attenuated. The threat of economic demise may be more apparent the more competitive the market, and thus could provide compelling pressure for the firm to improve operations. In the case of perfect competition, for example, any union wage effect would appear to require some offsetting productivity gain to ensure survival. Yet pressure to improve operations is usually presumed to be present in highly competitive markets without unionization, leaving no possibility of further improvements after the union is introduced. If as before attention is confined to the set of firms exercising some market power, then the potential for improvement would seem to be greater in less competitive markets since organizational slack, or x-inefficiency is likely to increase with market share. ${ }^{24}$ Whether potential gains are 
realized, however, depends on the presence of pressure from sources besides other competitors. Even though market-based pressure may be less, for example, the internal pressure imposed by the union could motivate a search for new methods and procedures which improve operating performance and offset, perhaps partially, any union wage gains and inefficient work rules. Furthermore, a vigorous organizational response to unionization could be observed in high market share firms if satisficing behavior is important in less competitive markets, and if the union threatens to reduce firm performance below satisfactory levels. ${ }^{25}$

In light of the empirical evidence on the union wage effect and market structure, the preceding argument suggests that the union impact on profitability may well be greater in firms with less market power, even if all firms experience some positive union productivity effects. If the more powerful firms are better able to recoup wage increases by altering internal organization the tendency for competition to sharpen the impact of the union will be reinforced.

The theoretical analysis in this section suggests that the impact of the union on various indicators of firm performance depends on technology, the wage setting process and market structure. The basic qualitative results are summarized in Table 1 . It is clear that inferences about the net efficiency consequences of the union based on a single indicator like productivity or profitability may be misleading. Evidence about productivity is incomplete without information on wage differentials and even then, any resultant changes in the rate of return on capital may convey information about the extent of substitution possibilities, but little else. Similar conclusions apply to other 
Table 1

Unionization and Firm Performance: Theoretical Predictions

Bargaining Regime*

\begin{tabular}{|c|c|c|c|c|}
\hline \multirow[b]{2}{*}{$\begin{array}{l}\text { Indicators of } \\
\text { Firm Performance }\end{array}$} & \multicolumn{2}{|c|}{ On the Demand Curve } & \multicolumn{2}{|c|}{ On the Contract Curve } \\
\hline & $\begin{array}{c}\text { Wage } \\
\text { Effect } \\
\text { Only } \\
\end{array}$ & $\begin{array}{l}\text { Wage and Off- } \\
\text { setting Produc- } \\
\text { tivity Effect }\end{array}$ & $\begin{array}{l}\text { Wage } \\
\text { Effect } \\
\text { Only }\end{array}$ & $\begin{array}{l}\text { Wage and Off- } \\
\text { setting Produc- } \\
\text { tivity Effect }\end{array}$ \\
\hline$Q / L$ & 0 & + & 0 & + \\
\hline $\mathrm{Q}$ & - & 0 & 0 & + \\
\hline$\pi / K$ & ? & ? & - & - \\
\hline
\end{tabular}

*Except where noted, the entries refer to the single firm model. In general it is the magnitude and not the signs which depend on market structure. Note also that the signs on $Q / L$ assume that the capitallabor ratio is held constant.

w*In the monopoly model, the sign depends on $\sigma$; with competition, the sign is more likely to be negative.

**:The sign depends on $\sigma$. 
indicators taken in isolation. A finding, for example, that unionization has no effect on growth could result from a bargaining model of wage determination, and need not imply the existence of a productivity dividend. Adding information on productivity (and other indicators) is thus essential. Only evidence on the pattern of effects over a number of indicators yields insight into the consequences of unionization.

\section{Empirical Analysis}

The analysis of Part I focused on three indicators of firm performance, each of which may be affected by unionization. The approach in the theoretical analysis has been to treat the two effects of unionization - wages and productivity - in the context of a reduced form equation for firm performance. In the case of profits, for example, the effect of the union is gauged through the following expression:

$$
\pi=B\left[A_{0} e^{\lambda T}(1+d U)\right]^{\eta}\left[g\left(w_{o}(1+m U), r\right)\right]^{1-\eta}
$$

Clearly, profits and other measures of performance depend on technology, exogenous factor prices, the structure of markets and the nature of demand. Unionization is assumed to affect performance through changes in wages and through its effect on productivity. While the various dimensions of performance are clearly related to one another, the intent is not to estimate a structural model of performance but to identify the impact of unionization in otherwise comparable enterprises. The general approach, therefore, is to estimate a set of reduced form equations which relate indicators of performance to a similar set of control variables (including unionization) which are treated as exogenous or predetermined. 
The analysis makes use of micro data on individual "business units" - generally divisions of a given corporation - which are referred to as the "firm." The indicators of firm performance are defined as follows :

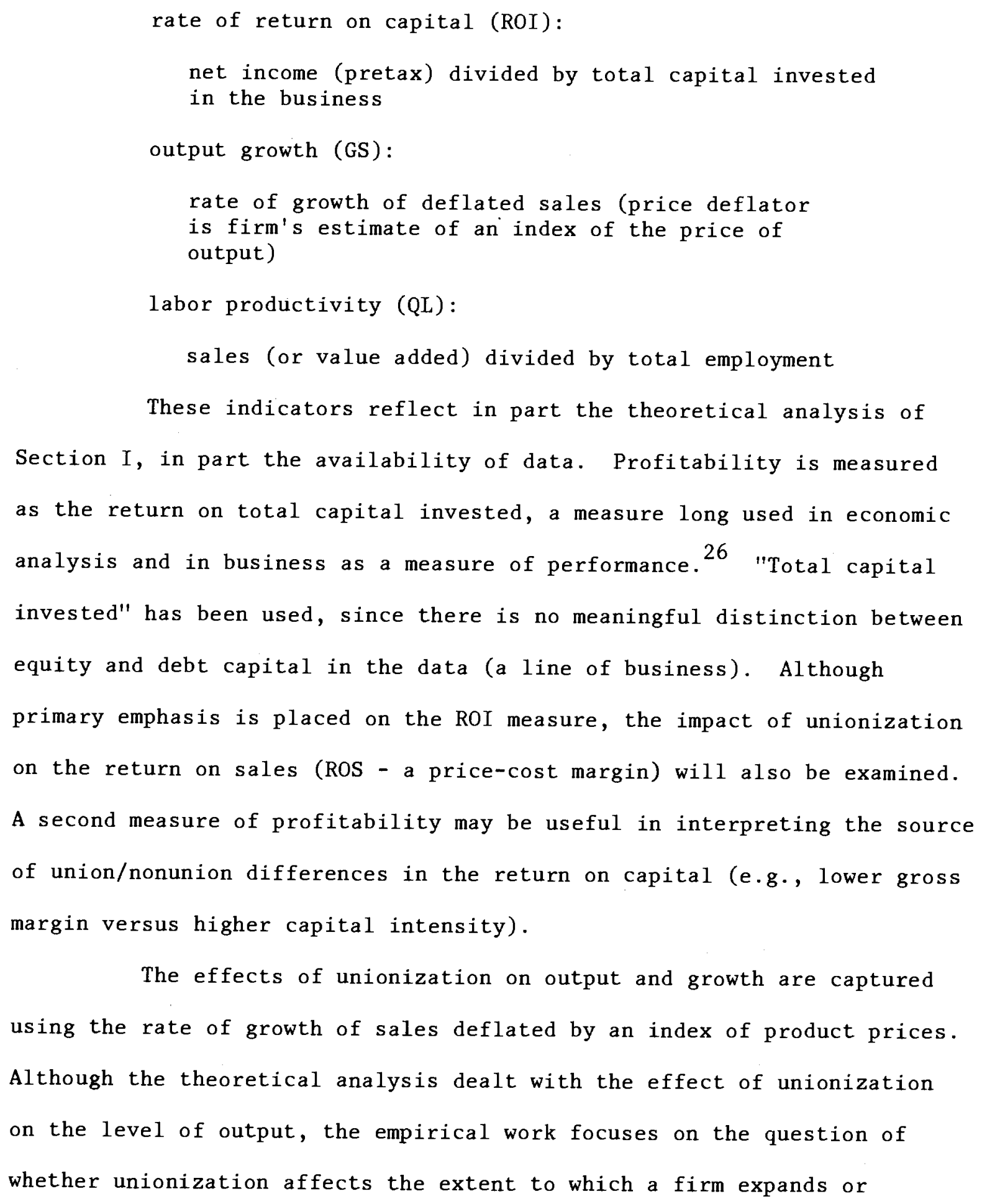


contracts relative to its market. The only variable close to the theoretical output measure is the firm's market share. While results with market share will be discussed, this variable may be less a measure of performance (at least current performance), and more a measure of structural conditions in the market.

The productivity analysis uses two measures, sales per employee and value added per employee. While it would be desirable to have better measures of labor input (hours worked, more detailed categories of employment) they are not available. In addition, the only price information available is the firm's estimate of its own selling price expressed as an index, with $1973=1.00$. Without cross-firm variation in the level of prices, only sector-specific price deflation (e.g., 2-digit SIC) will be possible. As discussed below, an attempt will be made to control for variation in the ratio of materials to labor and the capital-labor ratio, and thus to estimate the effect of unionization on total factor productivity.

The equations to be estimated can be expressed in general terms as follows:

$$
\begin{aligned}
& \mathrm{ROI}_{i t}=\mathrm{ROI}\left(\mathrm{UN}_{i}, \overline{\mathrm{MF}}_{i t}, \overline{\mathrm{MI}}_{i t}, \overline{\mathrm{H}}_{i t}, \overline{\mathrm{T}}_{i t}\right) \\
& \mathrm{GS}_{i t}=\mathrm{GS}\left(\mathrm{UN}_{i}, \overline{\mathrm{MF}}_{i t}, \overline{\mathrm{MI}}_{i t}, \overline{\mathrm{H}}_{i t}, \overline{\mathrm{T}}_{i t}\right) \\
& \mathrm{QL}_{i t}=\mathrm{QL}\left(\mathrm{UN}_{i}, \overline{\mathrm{MF}}_{i t}, \overline{\mathrm{MI}}_{i t}, \overline{\mathrm{H}}_{i t}, \overline{\mathrm{T}}_{i t}, \mathrm{KL}_{i t}, \mathrm{ML}_{i t}\right)
\end{aligned}
$$

where for the $i^{\text {th }}$ firm at time $t, U N_{i}$ is a measure of unionization, $\overline{\mathrm{MF}}_{i t}$ is a vector of variables measuring the nature of the competitive environment in the firm's narrowly defined market, $\overline{\mathrm{MI}}_{i t}$ captures the market structure of the firm's larger industry, $\overline{\mathrm{H}}_{i t}$ is a vector of workforce characteristics, $\overline{\mathrm{T}}_{i t}$, is a technology vector, $\mathrm{KL}_{i t}$ is the firm's 
capital-labor ratio, and $\mathrm{ML}_{\text {it }}$ is the materials-labor ratio. (Note that the value-added version of (23) omits the materials-labor ratio.) The specification assumes that the price of capital is constant across firms; the inclusion of work-force characteristics is intended to control for variation in competitive wages, and in labor quality. A full listing of the variables included in the analysis is presented in Table 2.

For the most part, the models spelled out in equations (21)-(23) are straightforward. Performance depends on structural conditions, both outside the firm in its labor and product markets, as well as inside, in its technology. In practice, there is little information about technology and differences across firms in this dimension are captured by 2-digit SIC industry dummies and time trends. The data provide a richer set of control variables for market structure. Indeed, equations (21)-(23) depart from typical industry-level analysis in their specification of the firm's market structure, in the richness of the control variables, and in the dependence of productivity on market structure. In addition, the reduced form character of the analysis results in the presence of work-force characteristics (albeit industry-level characteristics, tenure, years of education, demographics) in equations explaining profitability and growth.

The principal concern of the analysis is estimation of the overall impact of unionization, and its impact in different competitive situations. Industry-level measures of market structure include barriers to entry, industry growth, concentration and the share of imports. The analysis assumes, however, that conditions in the firm's own narrowly defined market are the primary structural determinants of competition; this is the focus of the analysis of unionization and market structure. 
Table 2

Control Var1ables - Def Initions and Sources*

\begin{tabular}{|c|c|c|}
\hline Vartable & Def Init ion & Source \\
\hline \multicolumn{3}{|c|}{ F1rm Control } \\
\hline LKL & $\begin{array}{l}\text { Log of total Investment per employee; } \\
\text { total investment Includes net plant } \\
\text { and equipment and working capital }\end{array}$ & PIMS \\
\hline LML & $\begin{array}{l}\text { Log of purchased materials per } \\
\text { employee }\end{array}$ & PIMS \\
\hline MS & Share of served market (In percent) & PIMS \\
\hline BIG3 & $\begin{array}{l}\text { Market share of three largest compet1- } \\
\text { tors (In percent) }\end{array}$ & PIMS \\
\hline COMP & Number of competitors & PIMS \\
\hline CPUR & $\begin{array}{l}\text { Percentage of Immediate customers } \\
\text { that account for } 50 \% \text { of business' } \\
\text { total sales }\end{array}$ & PIMS \\
\hline EXPER & $\begin{array}{l}\text { Approximate age of business (years } \\
\text { since first commercial sale) }\end{array}$ & PIMS \\
\hline RMG & $\begin{array}{l}\text { Rate of growth of real market sales; } \\
\text { (total market sales deflated by } \\
\text { estimated market prices) }\end{array}$ & PIMS \\
\hline \multicolumn{3}{|c|}{ Industry Market } \\
\hline INDG & $\begin{array}{l}\text { Average rate of growth of sales in } \\
\text { business' 4-digit SIC Industry over } \\
\text { 10-year pertod preceding business' } \\
\text { entry into sample }\end{array}$ & $\begin{array}{l}\text { PIMS/Census and Annual } \\
\text { Survey of Manufactures }\end{array}$ \\
\hline INDC4 & $\begin{array}{l}\text { Four firm concentration ratio in } \\
\text { business' 4-digit SIC Industry }\end{array}$ & $\begin{array}{l}\text { PIMS/Census and Annual } \\
\text { Survey of Manufactures }\end{array}$ \\
\hline INDIMP & $\begin{array}{l}\text { Share of Imports in sales in bus } 1- \\
\text { ness' 4-digit SIC industry }\end{array}$ & $\begin{array}{l}\text { PIMS/Census and Annual } \\
\text { Survey of Manufactures }\end{array}$ \\
\hline $\cos T$ & $\begin{array}{l}\text { Cost disadvantage ratio of } 3-\mathrm{d} \text { igit } \\
\text { SIC Industry }\end{array}$ & $\begin{array}{l}\text { Annual Survey of } \\
\text { Manufacturers }\end{array}$ \\
\hline \multicolumn{3}{|c|}{$\frac{\text { Industry Labor }}{\text { Market (H) }}$} \\
\hline RGN $(1,2,3)$ & $\begin{array}{l}\text { Fraction of shipments in Northeast, } \\
\text { South and West for the firm's 3- } \\
\text { digit (SIC) Industry }\end{array}$ & Census of Manufactures \\
\hline TEN & $\begin{array}{l}\text { Average years of tenure in the firm's } \\
3-d 1 g \text { it (SIC) Industry - } 1973\end{array}$ & $\begin{array}{l}\text { Gurrent Population Survey } \\
\text { January } 1973\end{array}$ \\
\hline GRD & $\begin{array}{l}\text { Mean grade attended by employees } \\
\text { In the f1rm's 3-dig1t (SIC) } \\
\text { Industry - } 1970\end{array}$ & 1970 Census of Population \\
\hline AGE & $\begin{array}{l}\text { Mean age of employees in the firm's } \\
\text { 3-dig1t (SIC) Industry - } 1970\end{array}$ & 1970 Census of Population \\
\hline BLK & $\begin{array}{l}\text { Percent of nonwhite employees in } \\
\text { the firm's 3-digit (SIC) Industry }\end{array}$ & 1970 Census of Population \\
\hline FEM & $\begin{array}{l}\text { Percent of female employees in } \\
\text { the firm's 3-digit (SIC) Industry }\end{array}$ & 1970 Census of Population \\
\hline
\end{tabular}


Three variables are used to characterize the competitive environment the firm faces: the market share of the three largest competitors, the number of competitors and the firm's own market share. These variables are intended to capture the size distribution of competitors, the difficulty of anticipating competitor reaction, and the firm's relative position. A variety of alternative measures of market structure using combinations and permutations of these variables - e.g., marginal concentration ratios, the Herfindahl index - were examined in the course of the empirical work but were found to provide no additional insight or explanatory power. It should be emphasized that the definition of the market and what constitutes a competitor are defined by the reporting business. Thus, the variables should be interpreted as measures of market structure as perceived by the firm.

The market structure variables enter the equations for profitability and productivity, but the firm's market share has been excluded from the growth equation to avoid redundancy. In the productivity equation, market structure is included to capture any $x$-efficiency effects or effects which may flow from relative size.

The unionization variable is based on the firm's response to the question: "Of all the employees in this business, what percentage are unionized?" The questionnaire makes no attempt to define what "unionized" means. Moreover, given the breadth of the work force involved ("all employees") there is likely to be a good bit of error in the estimates. Fine distinctions between firms are not likely to be meaningful. It is much more realistic to assume that the respondents will accurately identify whether a business is completely nonunion, or whether 
the fraction unionized falls in a broad range (e.g., 30\%-60\%). Most of the analysis, therefore, will use dummy variables to capture the union/ nonunion distinction, rather than relying solely on variation in the percentage unionized.

Before examining the source of the data in more detail, a brief word about the exogenous variables in equations (21)-(23) may be useful. As noted at the beginning of this section, I treat unionization, market structure and other control variables on the right-hand side of (21)-(23) either as exogenous or predetermined. A few of the variables are affected by the firm's decisions and their use raises the issue of simultaneity bias in the coefficients. Two variables deserve particular mention: the firm's market share, and unionization. 27

The market share of the firm provides information about the elasticity of demand and the firm's position relative to its competitors, characteristics of the market which are likely to have a major impact on profitability and which may affect productivity. I assume that these are structural features of the competitive environment, and are not affected by current profitability or productivity (the two equations where market share enters). It is clear that performance will affect structure over time, but existing evidence suggests that the lags are likely to be quite lengthy. ${ }^{28}$ of course, this assumption may be more tenuous for rapidly growing markets, particularly where products and firms are not well established. In order to test the sensitivity of the conclusions about union impact to the inclusion of market share, equations where market share is excluded will be estimated. 
A further critical assumption in model specification is the exogeneity of unionization. At issue is whether estimated coefficients on the union variables capture the impact of unionization, or whether they also reflect the process through which establishments are organized (e.g., unions organize the least (or most) profitable firms). The view that unionization is exogenous finds some justification on empirical grounds. For the great majority of unionized firms in this sample, union status was achieved prior to the time period covered by this data. Direct simultaneity is thus unlikely. It is of course possible that unionization could be correlated with an unobserved "firm effect" which persists through time, thus creating a correlation between union status and the error terms in equations (21)-(23). But the unobservable character of the effect, and the difficulty of predicting profitability (or other performance measures) far into the future based on observables, makes this possibility unlikely.

The Data Set

The data used in the empirical work provide fairly detailed information on performance, technology, market characteristics and union status. Data are available on over 900 product-line businesses which participate in the PIMS project directed by the Strategic Planning Institute. $^{29}$ The Institute is composed of over 250 member companies which participate in the project by supplying annual data on individual businesses within the company. Data are currently available from 1970-80. Not all businesses provide data for each year so that the design of the data base is unbalanced. In addition to income statements and balance sheets, the data set includes variables measuring the structure 
of the market in which the firm participates, and the competitive strategy of the business.

The data have a number of features which may affect interpretation of the results. The companies in the project tend to be large, diversified corporations; many are found in the Fortune 500 , and almost all of them are found in the Fortune 1000. The analysis thus deals with the effects of unionization among a set of firms which are not representative of all firms in a given sector, but which account for a significant fraction of the assets and people employed. Because the unit of observation is a line of business, a given company may report on several businesses. The businesses tend to be synonymous with operating divisions of the company (e.g., the washer and dryer division of the Diversified Appliance Corporation), but may include product lines within the division (e.g., commercial washers and dryers) if the appropriate data are available, and if the finer breakdown is useful to the company. The definition of each business is thus left for the companies to decide, although guidelines for the selection are provided by SPI. ${ }^{30}$ The lack of a uniform definition of the unit of observation should be kept in mind when interpreting the results.

The data provided by the respondent companies are a mixture of information available through accounting systems, and the respondent's perceptions or assessments of particular variables. Thus, the rate of growth of sales, or the gross book value of plant and equipment are provided by the accounting system. Data on the number of competitors, or the firm's share of the served market reflect the perceptions of the respondent; the data sre not computed from information provided by outside sources or other participating businesses in the same industry. 
The self-reported character of the data raises a question about its integrity. Two considerations suggest the data are of relatively high quality. First, the information requested is information of great value to the firm (e.g., its market share) and it seems reasonable to suppose that the firm is both in a position to know, and has expended effort to acquire accurate data. Second, a firm's participation in the project is motivated by a desire to use its data in the models developed by SPI. Considerable effort is made to preserve confidentiality and ensure quality: participating firms only have access to their own data; sensitive data (profits) are reported in disguised or ratio form (e.g., return on sales); researchers at SPI run the data through an elaborate procedure to check for consistency and follow-up gross errors with the company .

The Evidence

Table 3 presents means and standard deviations for selected variables. The calculations are broken down by union and nonunion status, and are based on data for North American (predominantly U.S.) manufacturing businesses over the period 1970-80. Each firm-year is treated as a separate observation, though some firms are not represented in each year. There are 902 firms in the sample, and thus an average of about five observations per firm (there are 4,681 observations in total). 31

It is evident from the calculations that the unionized firms are substantially older, and participate in markets that are growing some what less rapidly than their nonunion counterparts. They tend to confront about the same number of competitors, and to compete in markets where the largest firms have a slightly larger share of the market. As far as performance is concerned, the raw means suggest that nonunion firms are more profitable, and that their sales are growing more 
Table 3

Means and Standard Deviations

Total, Union and Nonunion Samples, 1970-1980

\begin{tabular}{|c|c|c|c|c|c|c|}
\hline \multirow[b]{2}{*}{ Variable } & \multicolumn{2}{|c|}{$\begin{array}{c}\text { Total } \\
(\mathrm{N}=4681)\end{array}$} & \multicolumn{2}{|c|}{$\begin{array}{c}\text { Union } \\
(\mathrm{N}=3246)\end{array}$} & \multicolumn{2}{|c|}{$\begin{array}{l}\text { Nonunion } \\
(\mathrm{N}=1435)\end{array}$} \\
\hline & Mean & Std. Dev. & Mean & Std. Dev. & Mean & Std. Dev. \\
\hline ROI & 21.5 & 25.6 & 20.6 & 24.4 & 23.5 & 28.1 \\
\hline ROS & 9.0 & 11.5 & 8.7 & 10.6 & 9.5 & 13.4 \\
\hline GS & 9.2 & 28.8 & 8.1 & 28.0 & 11.6 & 30.3 \\
\hline LVL & 3.28 & 0.57 & 3.28 & 0.54 & 3.27 & 0.65 \\
\hline LSL & 3.89 & 0.61 & 3.90 & 0.58 & 3.85 & 0.66 \\
\hline LKL & 7.78 & 0.71 & 7.80 & 0.68 & 7.75 & 0.79 \\
\hline LML & 7.57 & 0.85 & 7.61 & 0.82 & 7.48 & 0.90 \\
\hline$\%$ UN & 41.6 & 32.8 & 60.0 & 21.2 & - & - \\
\hline MS & 22.6 & 18.8 & 22.6 & 18.2 & 22.6 & 20.0 \\
\hline BI G3 & 46.9 & 18.5 & 47.1 & 18.2 & 46.5 & 19.2 \\
\hline COMP & 13.9 & 13.2 & 13.9 & 12.9 & 14.0 & 14.0 \\
\hline CPUR & 13.5 & 11.2 & 13.3 & 10.9 & 13.9 & 11.7 \\
\hline EXPER & 25.8 & 15.4 & 28.6 & 15.0 & 19.6 & 14.6 \\
\hline RMG & 4.9 & 21.8 & 4.3 & 21.4 & 6.5 & 22.5 \\
\hline INDG & 8.2 & 4.9 & 7.9 & 4.5 & 8.9 & 5.6 \\
\hline INDC 4 & 47.5 & 24.2 & 48.1 & 23.5 & 46.2 & 25.6 \\
\hline INDIMP & 4.7 & 6.1 & 4.9 & 6.4 & 4.2 & 5.3 \\
\hline $\operatorname{cosT}$ & 0.12 & 0.20 & 0.12 & 0.21 & 0.10 & 0.18 \\
\hline
\end{tabular}


rapidly - even more than could be accounted for by faster market growth. In terms of market share, however, there is no difference in the average levels. On the productivity side, union firms have a slight edge ( 1 percent) in value added per employee and a somewhat larger advantage in sales per employee; although firm conclusions await statistical analysis, it appears that the productivity differences may reflect differences in capital and materials per employee.

Estimates of various specifications of equations (21)-(23) are presented in Table 4. Results with three sets of control variables are examined. The first (control 1) uses a set of 2-digit (SIC) dummies, a time trend and a set of time-industry interaction terms. ${ }^{32}$ The interaction setup allows each industry to have its own time trend, and is equivalent to using industry-level deflators. The second set (control 2) of controls adds all the variables on market structure and labor markets from Table 2, except the firm's own market share. The final set (control 3) adds market share and market share squared, and two variables which measure the fraction of sales or purchases made to or from components within the parent corporation (these variables control for differences in transfer prices).

In general, the evidence points to a sizeable negative effect of unionization on profits, and small or insignificant effects on other measures of performance. Consider first the union impact on ROI in line 1. The negative coefficient on the union dummy in line la suggests a decline of ROI of about 12 percent. Once additional controls for market structure and industry labor markets are added, however, the estimated effect increases to -4.1 percentage points, or a decline of about 19 percent relative to the sample mean. While the market share 


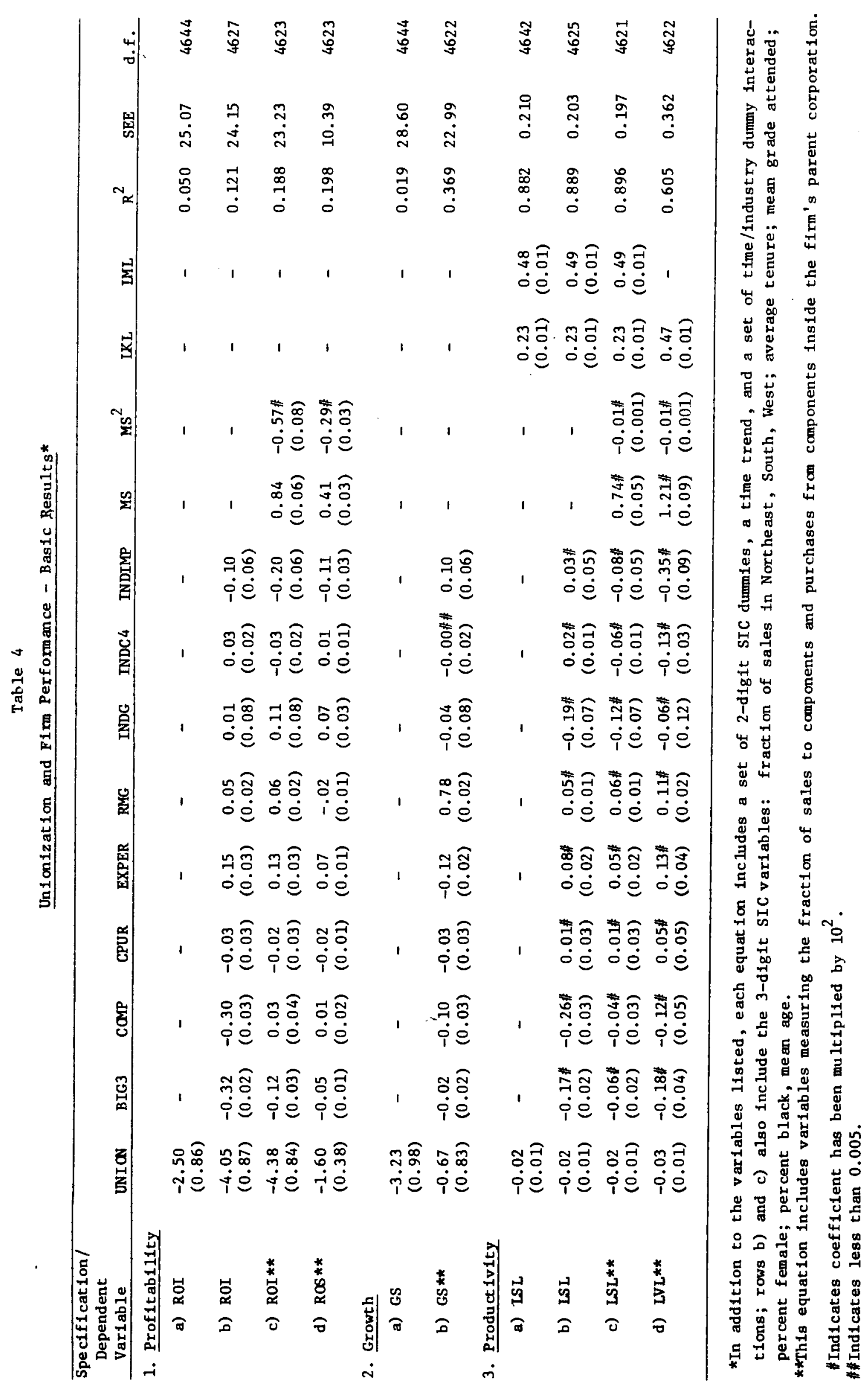


variables in line lc are highly significant, they have little effect on the union coefficient.

A negative union effect is also evident when profitability, is measured by the return on sales. Only the results with the full model are presented (line $1 \mathrm{~d}$ ) but the results with other specifications are similar. The size of the coefficient implies about an 18 percent lower return on sales in union firms. The size and significance of the ROS effect suggests that the decline in ROI arises primarily from a decline in total profits, rather than an increase in capital intensity. Indeed the similarity in the percentage changes in ROI and ROS implies that unionization has only a small effect on the ratio of sales to total capital. 33

The large negative union effects in the profit equations are not repeated in the growth or productivity equations. Although significantly negative in line $2 \mathrm{a}$, the union effect on the rate of growth relative to the market is small and statistically insignificant, once the characteristics of the market are introduced. The specification reported in line $2 \mathrm{~b}$ allows the market growth rate (RMG) to enter unconstrained. Estimates were also obtained with the RMG coefficient set equal to 1 . The results were literally unchanged - the union coefficient was -0.67 with a standard error of 0.83 .

The evidence in line 2 implies that there is little difference in the way union and nonunion firms participate in the growth of the markets in which they operate. While this finding sheds some light on the effect of unionization, it does not rule out the possibility that unionization causes a one-shot decline in output relative to 
the market. In order to examine this possibility, real growth was replaced with the firm's market share as the dependent variable. The union coefficient in the specifications corresponding to $2 a$ and $2 b$, were (with standard errors in parentheses): $-0.016(0.62)$, and $0.65(0.52)$. When other measures of the firm's market structure were omitted, the union effect was $-0.20(0.64)$. There is thus no evidence of a union effect on the firm's share of its served market. Since market share reflects structural conditions in the market, the absence of a union effect may only suggest that union and nonunion firms operate in similar competitive environments. However, it would seem likely that a sizeable negative union effect on the firm's output would register in these data.

The analysis in line 3 of Table 4 turns to the question of the union productivity effect. Here, labor productivity is measured by sales and value added per employee. Inclusion of LKL and LML in the equation means that the union coefficient measures differences in total factor productivity. As the results indicate, the choice of dependent variable has little effect on the union coefficient, although the sales specification in which materials and capital are included on the right-hand side is statistically superior. Unlike the results for profits and output growth, the union effect on productivity is unaffected by the inclusion of the control variables. Even though many of the structural variables are themselves significant, the union effect is estimated at $-0.02(0.01)$ with or without them. When value added is used, the union effect rises to $-0.03(0.01) .^{34}$ 
While the union coefficient in the sales specification is twice the size of its standard error, it is substantively small; moreover, with over 4,600 observations, the power of the evidence that the effect is different from zero is not overwhelming. Yet these results stand in contrast to the results of Brown and Medoff, who found a positive union productivity effect using data on 2-digit SIC industries by state. ${ }^{35}$ Moreover, the results are contrary to some findings based on specific industries. ${ }^{36}$ Reconciliation of these disparate findings is beyond the scope of the current paper, but it is possible to put the results here in some perspective. It must be remembered that the PIMS sample is not a random sample of firms in the manufacturing sector. Furthermore, the unit of observation here is not the establishment. The productivity measure refers to total employees of a business unit, and thus includes a variety of occupational categories (e.g., sales, managers, engineers, accountants) not included or not included with the same weight in the establishment-based Census of Manufactures. It should be noted, however, that when productivity equations were estimated controlling for the occupational mix in the firm's 3 -digit SIC industry no change in the results was obtained. It might be argued that failure to control for the blue collar/white collar mix would bias the union coefficient downwards since unionized establishments are likely to be more blue collar intensive, and would therefore be somewhat less productive than white collar intensive establishments (assuming white collar workers are more productive). That argument, however, makes little sense within a 3-digit industry where the technology of production would seem to leave little scope for large differences in occupational mix. 
Beyond the issue of comparability, it is important to note that the question of the union effect is ultimately an empirical question. There is no reason to suppose that the union effect has the same sign or magnitude in every industry. In fact, the average effect estimated in line 3 masks some differences across industries. Using the simple specification in line $3 a$, estimates of the union effect were obtained for each 2-digit industry. While the majority of the industry effects (and the bulk of the sample) were quite close to the average of -0.02 , positive union coefficients (6-17 percent) were found in textiles, furniture, and petroleum, and negative effects (4-18 percent) were found in lumber, stone, clay and glass, transportation equipment, and instrument manufacture. These estimates may reflect differences in the union/nonunion mix of component 3-digit industries, but they do suggest some diversity of effects. Evidence from previous industry case studies suggests that the nature of the union's impact on productivity depends on a complex interaction between management adjustment and union policy and action, which may well differ across industries. ${ }^{37}$ On average, that interaction in the firms in this sample leads to little change in productivity, but the results suggest the need for further analysis of industry effects. Alternative Measures of Unionization

Thus far, the analysis has been based on a relative simple specification of unionization. The results in Table 4 are in effect comparisons of conditional means for union and nonunion firms. It is possible to construct additional measures of unionization which may enrich understanding of its impact. Three possibilities are pursued in Table 5. The first is simply to enter the percentage of employees unionized in place of the union dummy. The second breaks up the percent unionized variable 
into the three categories: less than 30 percent, between 30 and 60 percent, and over 60 percent. These two measures are combined in the third approach through the use of a linear spline function. For the problem at hand, the spline variables are written as:

$$
\begin{array}{rlrl}
\mathrm{Z} 30 & =\mathrm{U} & & 0 \leq \mathrm{U}<30 \\
& =30 & & \mathrm{U} \geq 30 \\
\mathrm{Z} 60 & =0 & & 0 \leq \mathrm{U}<30 \\
& =\mathrm{U}-30 & 30 \leq \mathrm{U}<60 \\
& =30 & \mathrm{U} \geq 60 \\
\mathrm{Z} 60+ & =0 & & 0 \leq \mathrm{U}<60 \\
& =\mathrm{U}-60 & \mathrm{U} \geq 60
\end{array}
$$

where $\mathrm{U}$ is the percentage unionized. The variables are constructed to eliminate discontinuities at the breakpoint, and to allow the union effect to vary with the percent organized, with different slopes in the different ranges. The coefficients on these variables measure the slope of the function over the specified range.

The alternative measures of unionization are examined in Table 5, using the full set of control variables (control 3) as defined in Table 4. It is evident that the basic results on profitability, growth, and productivity are little affected by the new forms of the union variable, although some interesting patterns emerge in the comparisons between measures. A large negative effect on profitability is found under all specifications, but the monotonicity of the effect implied by the use of percent organized is dubious. The spline function shows a strong negative effect from 0 to 30 percent, and then no significant slope thereafter; the slope over the final range is actually positive. Use of three dummy variables suggests some differences depending on percent organized, but statistically, the differences are not particularly significant. A comparison of the standard errors of estimate for these equations 


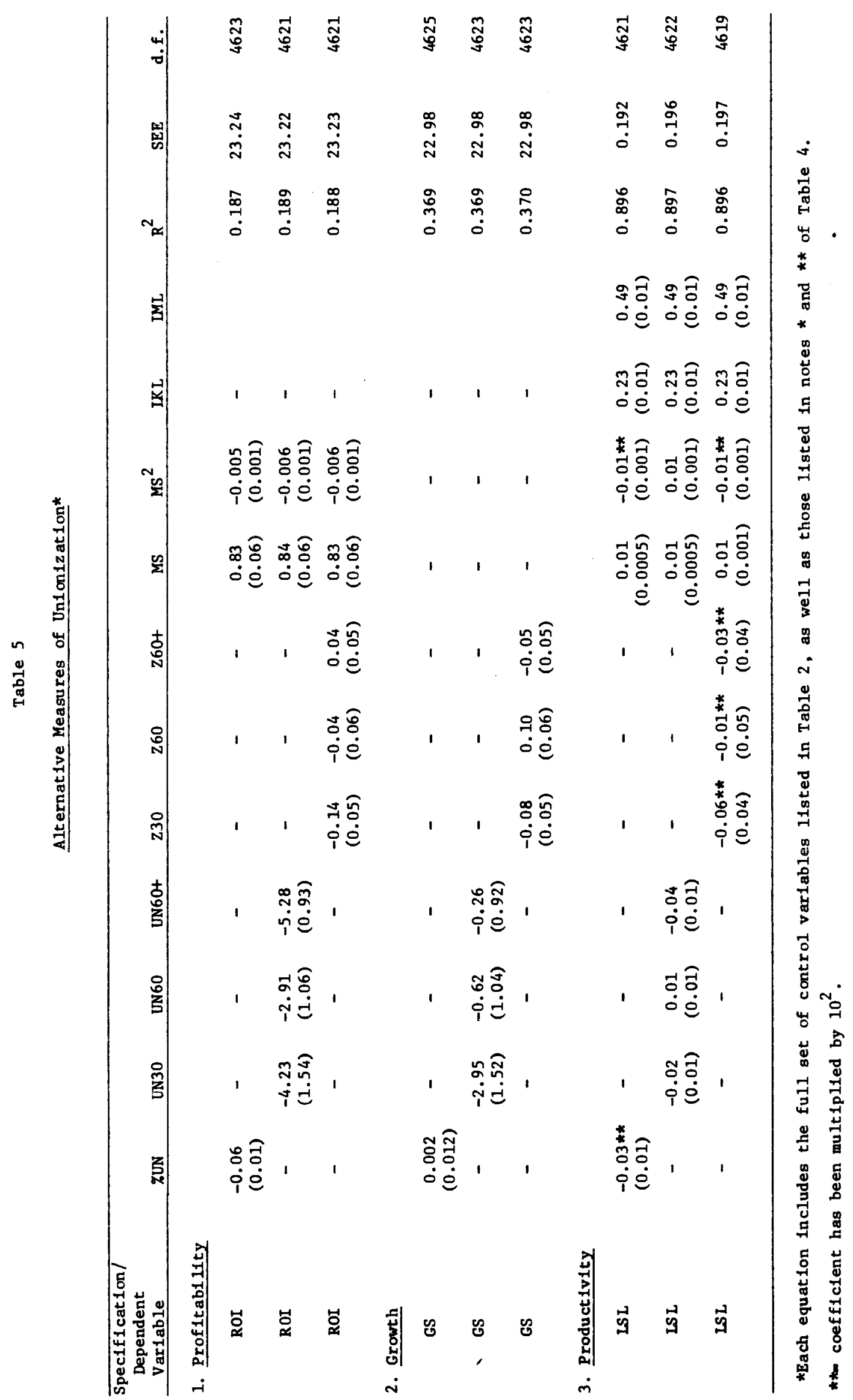


and the comparable equation (lc) in Table 4 shows that the alternative measures of unionization provide little explanatory power beyond the union dummy .

Similar statements apply to the growth and productivity equations. Although some differences in the various coefficients appear, the data appear to have little or very weak information about any differential effect of changes in percent organized. As noted earlier, this is likely to be a reflection of measurement error in the basic unionization variable. In light of the evidence, the remainder of the paper focuses on results with a simple dummy variable to capture the effects of unionization. Implications of the Basic Results

Seen in terms of the models developed in Section I, the results in Tables 4 and 5 appear to be inconsistent with the simple monopoly model with the firm on its demand curve. If the union wage effect in these data were in the proverbial 10-15 percent range, the profit results could imply an elasticity of substitution on the order of 2 . Yet, with a union wage effect, growth and market share in the simple model should have declined substantially; instead, the evidence suggests little change. Since productivity also changes very little, there appears to be some support for the simple bargaining model in which only a wage effect is present.

Additional evidence on the bargaining interpretation of these results is provided by examination of the capital-labor ratio. Neither capital nor labor should deviate from nonunion values in the face of unionization if wages are bargained through a process of joint profit maximization as described in Section I. Thus, if the bargaining model is correct, the union coefficient in an equation explaining the capitallabor ratio should be zero. 
Within the framework sketched out in Section I, the capital-labor ratio is determined by technology and relative prices, but is unaffected by market structure. In practice, it is important to control for differences in the market and industry, since the choice of technology is likely to be closely related to the types of products the firm manufactures. Evidence on the capital-labor ratio, therefore, is examined in the context of a model which includes controls for industry structure, technology, and labor market characteristics, but which excludes the firm's market share and the characteristics of its competitors. ${ }^{38}$

Table 6 presents estimates of the union effect on capital per employee under three specifications. The first includes only 2-digit industry dummies and industry-time interactions. The second adds controls for the labor market and the product at the 3- and 4-digit level. The third specification adds a set of controls for the extent of vertical integration (ratio of purchases to sales and share of internal components in those purchases), in order to control for differences in technology in the chain of supply. Results were obtained with arithmetic and logarithmic versions of the dependent variable, and in both cases the union effect is not significantly different from zero, once the control variables are added. In line lc, for example, the union dummy has a coefficient of -129.6 and a standard error of 89.1 . The effect is also substantively small: compared to the sample mean of 3174 , the union coefficient constitutes a decline of about 4 percent.

The difference in sign between the arithmetic and logarithmic versions suggested the possibility of outliers in the data. Examination of the residuals in equation lb revealed a small number (a little over 1 percent of the sample) of observations with residuals far from the 
Table 6

The Effect of Unionization on the Capital-Labor Ratio

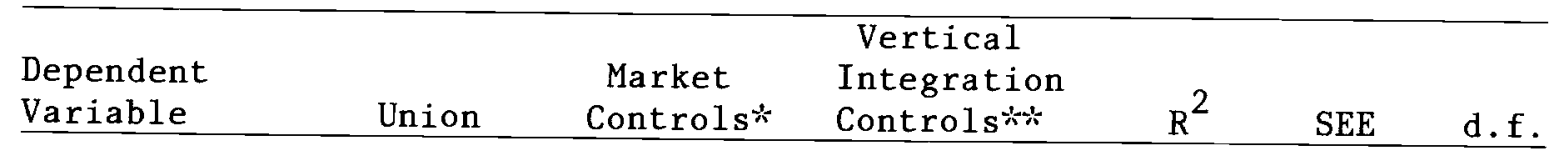

1. $\mathrm{K} / \mathrm{L}$

(arithmetic)

$\begin{array}{lcccccc}\text { a) } & -515.1 & - & - & 0.252 & 2607 & 4644 \\ & (89.2) & & & & & \\ \text { b) } & -168.1 & X & - & 0.311 & 2505 & 4630 \\ & (90.5) & & & & & \\ \text { c) } & -129.6 & X & X & 0.338 & 2456 & 4627 \\ & (89.1) & & & & & \end{array}$

2. LKL

(logarithmic)
a)
$-0.048$
$(0.021)$
- $\quad-$
0.267
$0.614 \quad 4644$
b)
0.030
$(0.021)$
$\mathrm{X}$
-
$0.315 \quad 0.595$
4630
c)
0.036
$\mathrm{X}$
$\mathrm{X}$
$0.352 \quad 0.579$
4627

*Includes all the variables in Control 2 (see Table 3), except BIG3; COMP and CPUR.

** Includes same variables as in a), and ratio of purchases to sales, and fraction of purchases from components of the parent corporation. 
median. These were primarily chemical processing firms, a sector in which extremely large values of capital per employee would be expected. Estimation without the outliers had no material effect on the magnitude of the coefficients. The conclusion that the union effect is not significantly different from zero is unaffected by discordant observations. Evidence on the capital-labor ratio thus provides further support for the bargaining interpretation of the union's impact on firm performance. Union Effects and Market Structure

It is obvious from the evidence developed in Tables 4-6 that unionized firms earn substantially lower returns than their nonunion counterparts. As far as other measures of performance are concerned, however, unionization appears to have only a minor impact. While the evidence is thus not inconsistent with a bargaining model of unionization and firm performance, broader inferences about the union's impact on the allocation of resources must be viewed with some caution. It might be inferred, for example, that unions affect the division of total excess return between workers and the firm, but have little impact on the use of real resources. Yet even if that characterization were to apply to the sample average, there may well be some diversity in the pattern of effects across competitive situations which could have real effects over the longer run. It matters whether the average effect reflects a situation in which the union extracts substantial gains from firms with monopoly power, leaving the competitive sector little changed, or whether the bulk of the union impact falls on firms with little market power.

The analysis in Section I suggested a number of reasons why the union's impact might be different in different contexts, and in fact, 
why the union may have a relatively larger impact on the smaller firms. Some insight into the effects of unionization in different environments is provided in Table 7 .

Estimates of the basic model are presented for subsets of the overall sample defined on the basis of market share. High market share firms are defined as those with more than 35 percent of the served market; the cutoff point for low-market share firms is 10 percent. This approach is relatively crude, since other aspects of the market may be important in determining the nature of competition and the firm's market power. A 10 percent share has a different meaning in a world where the principal competitors have 3 or 4 percent. While acknowledging the approximate nature of the approach, the use of market share should capture the basic tendencies in the data.

Estimates of the union effect on performance are presented in line 1 of Table 7; Table 8 provides mean values of the performance measures. The results are revealing. Unionization has an extraordinary effect on the return on capital in low-market share firms. Taken at face value, the estimated coefficient (-4.7) implies something close to a 40 percent decline in profitability due to unionization. A similar decline emerges in estimates using the return on sales. This large decline in profits among low-market share firms stands in contrast to the results for firms with substantial market power. The estimated effect in column 4 is statistically and substantively insignificant. Whereas unionized firms with less than 10 percent share earn much lower rates of return, profits among the "rich and powerful" appear to be little affected by unionization. 
Table 7

Union Impact in Different Competitive Environments*

\begin{tabular}{|c|c|c|c|c|c|c|}
\hline \multirow[b]{2}{*}{$\begin{array}{c}\text { Independent } \\
\text { Variables }\end{array}$} & \multicolumn{3}{|c|}{ Low-Market Share } & \multicolumn{3}{|c|}{ High-Market Share } \\
\hline & $\begin{array}{c}1 \\
(\mathrm{ROI})\end{array}$ & $\begin{array}{l}2 \\
(\mathrm{GS})\end{array}$ & $\begin{array}{c}3 \\
(\mathrm{LSL})\end{array}$ & $\begin{array}{c}4 \\
(\mathrm{ROI})\end{array}$ & $\begin{array}{c}5 \\
(\mathrm{GS}) \\
\end{array}$ & $\begin{array}{c}6 \\
\text { (LSL) }\end{array}$ \\
\hline UNION & $\begin{array}{l}-4.69 \\
(1.39)\end{array}$ & $\begin{array}{c}0.96 \\
(1.66)\end{array}$ & $\begin{array}{l}-0.03 \\
(0.01)\end{array}$ & $\begin{array}{l}-0.34 \\
(2.10)\end{array}$ & $\begin{array}{l}-1.51 \\
(1.90)\end{array}$ & $\begin{array}{l}-0.03 \\
(0.02)\end{array}$ \\
\hline BIG3 & $\begin{array}{l}-0.09 \\
(0.04)\end{array}$ & $\begin{array}{c}0.06 \\
(0.05)\end{array}$ & $\begin{array}{l}-0.01 * * \\
(0.03)\end{array}$ & $\begin{array}{l}-0.45 \\
(0.07)\end{array}$ & $\begin{array}{l}-0.03 \\
(0.06)\end{array}$ & $\begin{array}{l}-0.12 *-1 \\
(0.05)\end{array}$ \\
\hline COMP & $\begin{array}{c}0.01 \\
(0.05)\end{array}$ & $\begin{array}{c}0.06 \\
(0.06)\end{array}$ & $\begin{array}{l}0.01 \% * \\
(0.04)\end{array}$ & $\begin{array}{c}0.06 \\
(0.15)\end{array}$ & $\begin{array}{c}0.06 \\
(0.13)\end{array}$ & $\begin{array}{l}-0.12 *-12) \\
(0.12)\end{array}$ \\
\hline CPUR & $\begin{array}{l}-0.20 \\
(0.05)\end{array}$ & $\begin{array}{l}-0.07 \\
(0.07)\end{array}$ & $\begin{array}{l}-0.12 \% * \\
(0.05)\end{array}$ & $\begin{array}{c}0.24 \\
(0.08)\end{array}$ & $\begin{array}{c}0.06 \\
(0.08)\end{array}$ & $\begin{array}{l}0.18 * \div \\
(0.07)\end{array}$ \\
\hline EXPER & $\begin{array}{c}0.18 \\
(0.04)\end{array}$ & $\begin{array}{l}-0.18 \\
(0.05)\end{array}$ & $\begin{array}{l}0.15 * * \\
(0.04)\end{array}$ & $\begin{array}{c}0.24 \\
(0.07)\end{array}$ & $\begin{array}{l}-0.10 \\
(0.06)\end{array}$ & $\begin{array}{l}0.19 * * \\
(0.05)\end{array}$ \\
\hline RMG & $\begin{array}{c}0.04 \\
(0.03)\end{array}$ & $\begin{array}{c}0.63 \\
(0.03)\end{array}$ & $\begin{array}{l}0.05 * x \\
(0.02)\end{array}$ & $\begin{array}{c}0.11 \\
(0.04)\end{array}$ & $\begin{array}{c}0.82 \\
(0.03)\end{array}$ & $\begin{array}{l}0.10 * * \\
(0.03)\end{array}$ \\
\hline INDG & $\begin{array}{c}0.17 \\
(0.13)\end{array}$ & $\begin{array}{l}-0.14 \\
(0.15)\end{array}$ & $\begin{array}{l}-0.32 *-6 \\
(0.11)\end{array}$ & $\begin{array}{l}-0.24 \\
(0.21)\end{array}$ & $\begin{array}{l}-0.06 \\
(0.19)\end{array}$ & $\begin{array}{l}-0.14 * * \\
(0.17)\end{array}$ \\
\hline INDC4 & $\begin{array}{c}0.06 \\
(0.03)\end{array}$ & $\begin{array}{c}0.04 \\
(0.04)\end{array}$ & $\begin{array}{l}-0.08 * * \\
(0.03)\end{array}$ & $\begin{array}{l}-0.08 \\
(0.04)\end{array}$ & $\begin{array}{l}-0.05 \\
(0.03)\end{array}$ & $\begin{array}{l}-0.13^{2} \div ; \\
(0.03)\end{array}$ \\
\hline INDIMP & $\begin{array}{l}-0.33 \\
(0.13)\end{array}$ & $\begin{array}{c}0.41 \\
(0.16)\end{array}$ & $\begin{array}{l}-0.30 \% \\
(0.12)\end{array}$ & $\begin{array}{l}-0.42 \\
(0.15)\end{array}$ & $\begin{array}{l}-0.10 \\
(0.14)\end{array}$ & $\begin{array}{l}-0.20 * x \\
(0.12)\end{array}$ \\
\hline LKL & - & - & $\begin{array}{c}0.20 \\
(0.01)\end{array}$ & - & - & $\begin{array}{c}0.31 \\
(0.01)\end{array}$ \\
\hline LML & - & - & $\begin{array}{c}0.54 \\
(0.01)\end{array}$ & - & - & $\begin{array}{c}0.46 \\
(0.01)\end{array}$ \\
\hline $\mathrm{R}^{2}$ & 0.120 & 0.263 & 0.913 & 0.220 & 0.455 & 0.895 \\
\hline SEE & 21.39 & 25.43 & 0.191 & 24.74 & 22.32 & 0.198 \\
\hline d. f. & 1385 & 1385 & 1383 & 894 & 894 & 892 \\
\hline
\end{tabular}

*In addition to those listed, each equation includes a set of 2-digit SIC dummies; a time trend, a set of time 2-digit SIC interactions; and several 3-digit SIC variables: fraction of sales in Northeast, South, West; mean tenure; percent female; percent Black; mean grade attended; mean age.

*:The coefficient has been multiplied by $10^{2}$. 
Table 8

Means and Standard Deviations for High- and Low-Market Share Firms

\begin{tabular}{lcccc}
\hline & \multicolumn{2}{c}{ High-Market Share } & \multicolumn{2}{c}{ Low-Market Share } \\
Performance Measure & Mean & Std. Dev. & Mean & Std. Dev. \\
ROI & 34.7 & 27.3 & 11.1 & 22.4 \\
GS & 11.8 & 29.5 & 6.8 & 29.1 \\
LSL & 3.93 & 0.60 & 3.80 & 0.63 \\
\hline
\end{tabular}


The contrast is not nearly as sharp for the other performance measures. There appears to be some difference in the growth equation, with lower share firms having a positive union effect. But the coefficients are not significantly different. The estimated productivity effects are identical, although the coefficient for the high share firms has a larger standard error. For the low-market share firms, the pattern of effects across performance measures is much like the overall results in Table 4. Unionization is associated with a large impact on profits and small or negligible effects on productivity and growth. Among high share firms, however, unionization has no statistically significant impact on firm performance.

Estimates were also obtained for the balance of the sample. The results revealed a lower union impact on productivity as market share increased, but the decline does not appear to be smooth. Among firms with market shares of 10-20 percent, the data suggest a union effect of -2.4 (1.7), or about 12 percent of the mean. The estimates for firms with 20-25 percent of the market was $-5.8(1.8)$, or 22 percent, quite close to the sample average. In view of the fact that the effect vanishes among firms with over 35 percent market share, it seems clear that the high-market share firms in Table 7 form a distinctive group.

The theoretical analysis in section I provided several reasons why the impact of the union on profitability might be larger among firm's with less market power. Without information on relative wages (which is not available) it is not possible to draw firm conclusions, but the evidence appears to be consistent with studies which found little relationship between market structure and the union wage effect. In the context 
of the bargaining model, a constant union wage effect across market structure implies that unionization will fall more heavily on the less powerful firms .

While this line of thinking seems appropriate for most of the firms in this sample, a different explanation is likely to apply to those firms with substantial market power. The absence of a profit effect among high share firms could imply no union wage effect, but that is contrary to most of the evidence on the subject developed to date. A more appealing alternative relies on the possibility of limit pricing behavior. It does not seem far fetched to suggest that the firms in the high share group enjoy some barriers to entry (average market share $=50$ percent) and may be limit pricing. If so, no profit effect would be observed even if unions raise wages, as long as the union effect was reflected in the limit price. If the limit price were below the monopoly price, and if the union imposes a cost which would be borne by new entrants, the limit pricing firm will adjust the limit price to cover the added costs, leaving the price cost margin unchanged. 39

The evidence on market structure and union effects provides some perspective on the overall results, and suggests a number of interesting hypotheses about the union impact. The evidence on profitability is consistent with the models of competitive interaction developed in Section I. Unionization appears to bear most heavily on those firms whose profitability is already at a relatively low level. A disproportionate effect on less powerful firms raises the possibility that unionization influences processes of entry and exit and thus the structure of the market. This notion is not unreasonable. Williamson has argued precisely this point in the coal industry, and the effect of the UAW 
on the smaller automobile companies in the 1950s provides a further historical example. ${ }^{40}$ This obviously depends on the extent of organization in the industry and the ability of new or smaller firms to avoid unionization.

It is difficult to pursue these hypotheses in the PIMS data, since the observations pertain to a single firm, while the hypothesis involves the extent of unionization in an industry. Because the data set is not necessarily composed of observations on direct competitors, and because little information about competitors is available (e.g., the extent to which they are unionized), it is not possible to examine what are essentially industry dynamics. In this case one is left with suggestive results about the incidence of the union impact on profits and a number of working hypotheses about longer-term effects on competition; the need for further research is clear.

\section{Conclusions}

This paper has developed a framework for analyzing the effect of unionization on firm performance, and has provided empirical evidence on several indicators, including rates of return on total capital and sales, output growth, market share, productivity and the capital-labor ratio. The analysis provides clear evidence that, on average, unionized firms earn substantially lower returns than nonunion firms operating in comparable technological and competitive environments. It is also evident that other dimensions of performance, particularly, growth and capitallabor substitution, are little affected by unionization in this data. The evidence is thus consistent with a bargaining model of union-firm interaction, in which the union affects the distribution of profits, but has little effect on output, or factors of production. 
This characterization of the union's effect has some interesting implications. It explains why unionized firms may survive over long periods of time, and why the owners of capital would be strongly opposed to unionization. The evidence suggests further that the issue of the impact of the union on resource allocation is really a question about the long run. In this data, at least, efficiency effects would seem to derive from differences between firms with and without market power, and from differences between industries. Interpreted literally, the results point to factors which influence the maintenance of union organization, and exit and entry behavior as the key determinants of the union's impact on efficiency. One implication is that research on these problems could benefit from analysis of unionization in specific firms and industries with emphasis on the historical perspective. Such longitudinal analysis, if carried out over a period of time long enough to allow for entry and exit, would be a valuable addition to the literature.

These comments are not meant to imply that the questions about the union's impact on the firm which motivated this study have been answered. The analysis is suggestive of a possible interpretation, but it is well to remember that the evidence in favor of the bargaining model is largely negative: the data fails to reject the notion that unionization has no effect on output or factor use. Furthermore, the special nature of the PIMS data suggests caution in embracing the bargaining model as generally applicable. Even within the data set there is some indication that the impact of the union may differ in different competitive settings. Further analysis of the impact of the union on the firm, of possible differences in productivity effects by industry and of the role of the union in competitive dynamics within an industry seems warranted. 


\section{Footnotes}

1. The basic reference is Slichter, Healy and Livernash.

2. A review of these findings is contained in Freeman and Medoff (1980).

3. The papers by Freeman (1980), Brown and Medoff and Clark are representative.

4. Freeman and Medoff (1980), p. 81.

5. The model developed in this section is a special case, but it illustrates the point that the impact of a union induced wage increase on the rate of return on capital depends on the parameters of production and demand. Only in the case where the price of output is fixed does the union wage increase have an unambiguously negative effect on the rate of return on capital. This can be seen by expressing the rate of return on capital, as:

$$
\pi / K=\left[\frac{P Q}{L}-\frac{W L}{L}\right] /(K / L),
$$

and (with the price fixed) calculating the logarithmic differential. This yields:

$$
\mathrm{d} \ln \left(\frac{\pi}{\mathrm{K}}\right)=\frac{1}{1-\alpha}[\mathrm{d} \ln (\mathrm{Q} / \mathrm{L})-(1-\alpha) \mathrm{d} \ln (\mathrm{K} / L)]-\frac{\alpha}{1-\alpha} \mathrm{d} \ln W,
$$

where $\alpha$ is labor's share.

Assuming that the changes in these variables were caused by unionization, the term in brackets is the union productivity effect, while the change in the wage is the union wage effect. With no productivity effect, and assuming that unionization raises the wage, the rate of return on capital will fall. If the price is allowed to vary (i.e., if the firm is assumed to have a downward sloping demand curve) one obtains the same result as given in the text. In general, the direction of the effect also depends on the elasticity of demand and returns to scale.

6. Note that I have defined profits net of a required return to capital. Doing the analysis in terms of gross returns would change the magnitude of the calculated elasticities but would have no effect on the signs; since the required rate of return is assumed to be fixed, the sign of changes in the gross rate of return (required plus excess) arising from a wage increase depends on the sign of changes in the excess rate of return.

7. If returns to scale are not constant, then the sign of $\eta_{(\pi / k) w}$ will depend on the elasticity of demand, and the degree of returns to scale, as well as the elasticity of substitution. 
Footnotes (continued)

8. It is important to note that the effect of the union is assumed to apply to the production process as a whole, rather than to a particular factor of production. The assumption of a "neutral" productivity effect is roughly consistent with existing evidence that unionization affects all aspects of the enterprise. (See Clark and Slichter et al.) The notion that it affects them all equally, however, is only an assumption.

9. Warren-Boulton describes several such measures in his work on vertical control by unions.

10. The likely inefficiency of points on the demand curve is a central feature of the work of Hall and Lilien; for a recent treatment of the bargaining problem, see McDonald and Solow.

11. If the wage alone were subject to agreement, with the firm free to adjust output, prices and other factors, the firm would choose a point on its demand curve. Note that the bargaining model implicitly assumes that the relationship between the union and the firm persists indefinitely. A richer analysis would deal with the question of maintenance of organization.

12. See Warren-Boulton, pp. 119-156 for an intensive analysis.

13. This assumption has been used by de Menil and Rosen. The implication is that the union seeks to maximize the rents associated with bargaining collectively.

14. A neutral change in technology (to which a union productivity effect is equivalent) has two effects on factors of production. The first is a direct reduction in input requirements equal (in percentage terms) to the productivity effect. The second is an increase in requirements through lower prices and increased output; the second effect depends on the elasticity of demand. If $d$ is the productivity effect, the impact on $K$ and $L$, for example, is $d(\eta-1)$.

15. The assumption of differentiated products is crucial here. Without it, joint profit maximization would imply that $q_{l}$ would go to zero, with some kind of ex-post redistribution of profits. The analysis without differentiated products is equivalent to the problem of the multiplant monopolist.

16. This assumes that interdependence effects are minimal.

17. It should be noted that the mental experiment here is to compare an otherwise identical firm in two different market settings. The issue is not the profitability of the unionized firm relative to its competitors, but rather the differences in profitability within the same firm in the two different environments. 


\section{Footnotes (continued)}

18. This conclusion can also be illustrated in a model where a large firm is limit pricing behind barriers to entry. If unionization leads to an increase in average costs and an increase in the limit price, there will be no observed effect on profits, as long as the new limit price is less than the profit maximizing price. All of these examples are merely illustrative. Other models suggest different conclusions. For example, a Cournot model of duopoly implies that unionization of the smaller firm actually reduces margins by less than unionization of the larger firm. But this model abstracts from cross-price effects and assumes a common output price. I am indebted to Therese Flaherty for these examples.

19. Note that the firm is assumed to face the same pre-union wage no matter what the product market environment. With the same union differential it must be the case that post-union wages are identical. In a bargaining model, the post-union wage can be expressed as $w=\left((1-\theta) \pi^{*}\right) / \mathrm{L}$, where $\pi^{*}$ is total or pre-union profits, $\mathrm{L}$ is labor input, and $\theta$ is the firm's share of total profits. Note that $\theta$ also measures the extent of decline in the firm's profitability. Consider a firm in two environments, one a competitive situation (firm 1), the other a situation where the firm has much more market power (firm 2). Since post-union wages are equal, $\left(\left(1-\theta_{1}\right) \pi_{1}^{*}\right) / \mathrm{L}_{1}=\left(\left(1-\theta_{2}\right) \pi_{2}^{*}\right) / \mathrm{L}_{2}$. It is reasonable to expect $\pi_{1}^{*}<\pi_{2}^{*}$, and $\mathrm{I}_{1}>\mathrm{I}_{2}$. Thus, wages can only be equalized if $\theta_{1}<\theta_{2}$, which implies that profits must fall more in the competitive situation.

20. The discussion here abstracts from any rivalrous behavior. It is assumed that competitors accept reformulation of prices and outputs caused by the union. But it may be that competitors come out worse off, since some of the union's gains may come out of their profits. Whether the consensus holds up or breaks down may depend on the relative power of the unionized firm. Thus, even in the case of rivalrous behavior, it is likely that unionization will have less impact on the more powerful firm.

21. See the papers by Weiss and Segal for a discussion of the theoretical and empirical issues.

22. This argument is made by Weiss, who also finds some support for the queue explanation. Similar conclusions apply to the work of Ashenfelter and Johnson.

23. See Weiss, and Freeman and Medoff (1981); additional evidence can be found in the paper by Pugel. 


\section{Footnotes (continued)}

24. It is evident that such considerations apply only to firms enjoying some barriers to entry. The tendency for inefficiency to increase with market share has been inferred from the quadratic nature of the relationships between rates of return and market share. See especially the work by Shepherd.

25. The analysis has not treated the potential impact of unionization on market structure. While principal concern is with the effect of the union on the firm, it is clear that the extent of unionization within an industry could affect the nature of competition, both by affecting entry conditions, and communication about costs. Furthermore, if the union pursues a common wage policy, marginal competitors could be eliminated. The net result of these considerations is likely to be a larger impact of the union on less powerful firms.

26. The net income measure is based on conventional accounting practices which treat R\&D, advertising and other marketing costs as expenses. Neither income nor capital have been corrected for inflation in the results reported below. Capital is valued at historical costs and net income is taken as reported. However, a relatively crude attempt was made to restate capital in current prices, and to correct for profits on inventories. (The PIMS data provide an estimate of the replacement value of plant and equipment.) Since this correction was a very rough cut, and since it had no effect on the estimated impact of the union, results with the conventional profitability data are presented below.

27. The capital-labor ratio is also endogenous, but it is used to control for the effect of the union on productivity which works through wages. The union coefficient is thus to be interpreted as an estimate of d, the union effect on total factor productivity.

28. See the paper by Martin for estimates of the lagged relationship between performance and structure.

29. The PIMS data have been used in several analyses of strategy and performance. See in particular papers by Gale, Buzzell and Ravenscraft and Scherer.

30. The governing principles are that the business serve a well-defined set of customers, and face specific competitors.

31. The panel structure of the data does not permit estimation of a model with a fixed firm effect, since union status does not change within the sample period. It is possible that the efficiency of the regression could be improved by allowing for a more complicated covariance structure (e.g., across firms and overtime). However, the unbalanced nature of the design makes this approach computationally burdensome and it has not been pursued. 


\section{Footnotes (continued)}

32. Results with time dummies are very similar. Clearly, the crosssection variation in the data dominates variation over time.

33. This is in fact confirmed in the data. A regression with $(S / K)$ as the dependent variable using the full model has a union coefficient of $0.09(0.04)$. The mean of $\mathrm{S} / \mathrm{K}$ is 2.29 , which suggests a difference in $\mathrm{S} / \mathrm{K}$ of about 4 percent.

34. Some estimates were obtained with a union-time interaction term, but the overall results were little changed; the interaction term was not statistically or substantively significant.

35. See Brown and Medoff.

36. Clark and Frantz found positive union effects in the cement and furniture industries.

37. The most explicit treatment of this issue is found in Clark.

38. In effect, the industry variables play the role of 3- and 4-digit SIC industry dummies.

39. See the paper by Duchatelet and Flaherty for a theoretical analysis of limit pricing which suggests that it may be a more pervasive phenomenon than previously believed.

40. Macdonald documents the effect on the so-called "Independents" of UAW wage policy. In this case, some of the smaller firms (i.e., Studebaker) actually paid wages above those at the larger firms. This "pattern-plus" approach to bargaining between the UAW and the smalier companies may have affected the "Independents" ability to compete and may have contributed to their eventual demise. See Macdonald, pp. 258-306. 


\section{$\underline{\text { References }}$}

Ashenfelter, Orley and George Johnson. "Unionism, Relative Wages and Labor Quality in U.S. Manufacturing." International Economic Review. 13, October 1972.

Brown, Charles and James L. Medoff. "Trade Unions in the Production Process." Journal of Political Economy. 86. June 1978.

Buzzel1, Robert D, Bradley Gale, and Ralph G.M. Sultan. "Market Share--A Key to Profitability." Harvard Business Review. January-February 1975.

Clark, Kim B. "The Impact of Unionization on Productivity: A Case Study." Industrial and Labor Relations Review. 33, July 1980.

Duchatelet, Martine and M. Therese Flaherty, "Strategic Response to Entry Over the Product Life Cycle." Processed 1981.

Frantz, John. "The Impact of Trade Unions on Productivity in the Wood Household Furniture Industry." Honors Thesis, Harvard University, 1976.

Freeman, Richard B. "The Exit-Voice Trade off in the Labor Market: Unionism, Job Tenure, Quits and Separations." Quarterly Journal of Economics. 94, December 1980.

Freeman, Richard B. and James L. Medoff. "The Percent Organized Wage Relationship for Union and Non-Union Workers." Review of Economics and Statistics. 63, November 1981.

Freeman, Richard B. and James L. Medoff. "The Two Faces of Unionism." The Public Interest. 57, Fall 1979.

Gale, Bradley T. "Selected Findings from the PIMS Project: Market Strategy Impact on Profitability." American Marketing Association Combined Proceeding. (1974).

Ha11, Robert E. and David M. Lilien. "Efficient Wage Bargains Under Uncertain Supply and Demand." American Economic Review. 69, December 1979 .

Macdonald, Robert M. Collective Bargaining in the Automobile Industry (New Haven and London: Yale University Press, 1963).

McDonald, Ian M. and Robert M. Solow. "Wage Bargaining and Employment." American Economic Review. 71, December 1981.

Martin, Stephen. "Advertising, Concentration and Profitability: The Simultaneity Problem." The Bell Journal of Economics. 10, Autumn 1979. 


\section{References (continued)}

Pugel, Thomas A. "Profitability, Concentration and the Interindustry Variation in Wages." Review of Economics and Statistics. LXII, May 1980 .

Ravenscraft, David and F.M. Scherer. "The Lag Structure of Returns to R\&D." Processed 1981.

Rosen, Sherwin. "Trade Union Power, Threat Effects and the Extent of Organization." Review of Economic Studies. Vol. 36 (April 1969).

Segal, Martin. "The Relation Between Union Wage Impact and Market Structure." Quarterly Journal of Economics. 78, Feburary 1964.

Shephard, William G. "The Elements of Market Structure." Review of Economics and Statistics.

Slichter, Sumner, James Healy and Robert Livernash. The Impact of Collective Bargaining on Management. (Washington, D.C.: Brookings, 1960).

Warren-Boulton, Frederick R. Vertical Control of Markets: Business and Labor Practices. (Cambridge: Ballinger, 1978).

Weiss, Leonard. "Concentration and Labor Earnings." American Economic Review. March 1966. 